\title{
Optimal foraging and density-dependent competition in marine fish larvae*
}

\author{
Louis Fortier ${ }^{1}$, Roger P. Harris ${ }^{2}$ \\ ${ }^{1}$ Département de biologie, Université Laval, Québec, Canada G1K 7 P4 \\ ${ }^{2}$ Plymouth Marine Laboratory, Citadel Hill, Plymouth PL1 2PB, United Kingdom
}

\begin{abstract}
Ontogenetic migrations of fish larvae were studied in relation to vertical distribution of their prey and their predators at a single, unstratified, $60 \mathrm{~m}$ deep, station off Plymouth, UK. The vertical distribution of fish larvae was highly stratified. Diel migrations were weak. Marked ontogenetic migrations reflected a size-related shift in the equilibriurn between predation and starvation risks. Yolksac larvae concentrated in the top half of the water column where planktonic predators were the least abundant. As size increased, the overlap between the vertical distribution of the postlarvae and that of potential predators increased. Postlarval stages of species feeding on copepods were distributed in direct proportion to resource availability. This suggested an optimization of postlarval foraging behaviour in response to density-dependent competition for food. Calculations showed that the larvae themselves had little impact on their resource, but indications were found that the abundance of larval fish food was affected by other planktivorous predators. We conclude that the density-dependent competition for food suggested by the observed patterns of postlarval distribution could only be generated at the level of the entire assemblage of planktonic predators.
\end{abstract}

\section{INTRODUCTION}

The vertical migrations of planktonic animals can often be interpreted as a response to the conflicting constraints of avoiding predators and maximizing food intake (Iwasa 1982, Gliwicz 1986, Johnsen \& Jacobsen 1987). The equilibrium between predator avoidance and foraging efficiency will be modified if either predation or starvation risk varies (Milinski \& Heller 1978, Gliwicz 1986). Optimal foragers will adapt to a new equilibrium by modifying their foraging behaviour (Grubb \& Greenwald 1982, Iwasa 1982, Holbrook \& Schmitt 1988). At the time scale of the diel cycle for example, Daphnia stop migrating when food becomes scarce and remain in the near surface to maximize foraging at the expense of predator avoidance (Johnsen \& Jacobsen 1987). On an evolutionary time scale, the copepod Cyclops abyssorum has developed vertical migrations at the expense of foraging efficiency in lakes where predator fish have been stocked for several decades or centuries (Gliwicz 1986).

During the early ontogeny of fish, both predation and

- Contribution to the program of GIROQ (Groupe interuniversitaire de recherches océanographiques du Québec) starvation risks change dramatically. Initially, the small and slow-moving yolksac larvae are very vulnerable to planktonic (Bailey 1984, Hunter 1984, Purcell et al. 1987) or nektonic predators (Brownell 1985, Folkvord \& Hunter 1986), but their metabolism is fueled by endogenous reserves and starvation is unlikely. With the final resorption of the yolk reserves and the development of locomotion, metabolic demand for exogenous food increases, whereas vulnerability to predators decreases rapidly (Bailey 1984, Hunter 1984, Brownell 1985, Folkvord \& Hunter 1986, Purcell et al. 1987). In water columns where gradients exist in the vertical distribution of predators and prey, fish larvae should modify their vertical distribution during the first days of life, in response to this ontogenetic reversal in the relative importance of predation and starvation risks. Yolksac larvae should seek depths where predators are least abundant. As susceptibility to predation decreases and susceptibility to starvation increases, the postlarvae are expected to distribute according to the distribution of their prey.

The predictions of the Optimal Foraging Theory (OFT) concerning the co-distribution of foragers and their resource differ depending on whether or not density-dependent competition for food occurs (Fig. 1). 


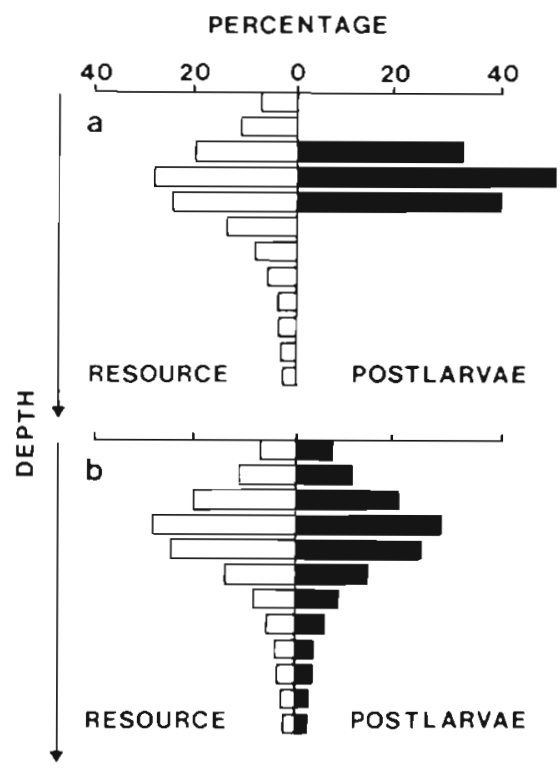

Fig. 1. Schematic representation of the vertical co-distribution of fish postlarvae (black histograms) and their resource (open histograms) when density-dependent competition does not occur (a) or does occur (b). Based on the predictions of Optimal Foraging Theory and the Ideal Free Distribution model (Fretwell \& Lucas 1970)

If there is no density-dependent competition, each individual is free to forage in the zone of highest food availability, and postlarvae will accumulate within the depth range of greatest prey abundance (Fig. 1a). If there is a potential for density-dependent competition, the concentration of the postlarvae at the depth of highest food availability will favour this competition and reduce the average individual gain in food. The Ideal Free Distribution (IFD) model predicts that if density-dependent competition does occur, fish postlarvae will redistribute in proportion to the percentage of the total resource available at a given depth (Fretwell \& Lucas 1970) (Fig. 1b). By thus spreading according to food availability, foragers reduce density-dependent competition and maximize the average individual gain in resource. The resulting distribution is termed 'Ideal Free' in reference to 2 assumptions of the model which are that the foragers select the most profitable or ideal site for survival and that they have free access to all sites (i.e. depths in the case of planktonic organisms). Assuming that predation becomes less important as size increases (Bailey 1984, Hunter 1984, Brownell 1985, Folkvord \& Hunter 1986, Purcell et al 1987), the relationship between the vertical distribution of the postlarvae and that of their resource should provide some insight as to whether density-dependent trophic interactions take place among fish larvae.

The aim of the present study was to describe changes in the vertical co-distribution of fish larvae, their prey and their predators, during the first days of larval life when the relative importance of predation and starvation risks shifts rapidly. In addition, possible densitydependent trophic interactions among fish postlarvae and other planktonic predators were investigated by using the predictions of the Ideal Free Distribution model as null hypotheses with which to compare the vertical distributions of larvae and postlarvae in the field. The study was not intended as a test of the Optimal Foraging Theory or the Ideal Free Distribution model since the verification of some of the underlying assumptions is difficult or impossible in field situations. As suggested by Hughes (1980), the theory and its underlying assumptions were used as a framework for the interpretation of the observed distributions, whether these deviated from or agreed with the predictions.

\section{MATERIALS AND METHODS}

The study was conducted in Eddystone Bay on the north coast of the Western English Channel. Tidal stream is moderate in the area $\left(<1.8 \mathrm{~km} \mathrm{~h}^{-1}\right)$. The thermocline develops in late April or May. The sampling station $\left(50^{\circ} 12.5^{\prime} \mathrm{N}, 04^{\circ} 40.0^{\prime} \mathrm{W}\right)$ was located 11 $\mathrm{km}$ offshore and $40 \mathrm{~km}$ to the WSW of Plymouth (UK). Depth at the station varied from 58 to $62 \mathrm{~m}$ depending on the tide.

A large-volume pump system was used to sample ichthyoplankton and zooplankton. The characteristics and the efficiency of the system are detailed elsewhere (Harris et al. 1986). Briefly, the submersible pump delivered $2.8 \mathrm{~m}^{3} \mathrm{~min}^{-1}$ of water through $15 \mathrm{~cm}$ diameter hosing, into a standard $200 \mu \mathrm{m}$ mesh plankton net suspended in a water-filled plastic bag. Part of the flow (280 $\mathrm{Imin}^{-1}$ ) was deflected into a smaller $80 \mu \mathrm{m}$ mesh plankton net for the collection of microzooplankton samples. A CTD system attached to the end of the $90 \mathrm{~m}$ intake hose allowed the recording of temperature and salinity, and the precise control of sampling depth. With the configuration used, passage time through the system was 35 s. Extensive tests at sea showed the pump to be as efficient, or in some cases significantly more efficient, than a vertical WP2 net in sampling zooplankton and fish larvae (Harris et al. 1986). Comparisons of day and night captures indicated little avoidance of the intake by fish larvae except by Clupeidae longer than $6 \mathrm{~mm}$ (Harris et al. 1986, see also Fig. 4 below).

Vertical profiling of plankton abundance was carried out at intervals of $3 \mathrm{~h}$ from 18:00 h (BST) 18 May to 06:00 h 21 May 1983. Each of the 21 profiles obtained consisted of 12 samples collected at $5 \mathrm{~m}$ depth intervals from $55 \mathrm{~m}$ to the surface $(1 \mathrm{~m})$. The pump intake was moved up from one discrete depth to the next every 10 min. The water pumped during the first minute was 
discarded to allow complete flushing of the system. The water pumped during the following 9 min was diverted to the nets, delivering a $22.7 \mathrm{~m}^{3}$ sample into the $200 \mu \mathrm{m}$ mesh net and a $2.5 \mathrm{~m}^{3}$ sample into the $80 \mu \mathrm{m}$ mesh net. Samples were preserved in $5 \%$ neutral formalin. Water samples corresponding to the net samples were collected at the pump output for the determination of chlorophyll a concentration and phytoplankton composition.

The abundance of microplankton taxa was determined by enumeration of the $80 \mu \mathrm{m}$ mesh collections. Ichthyoplankton and large zooplankton were sorted from the $200 \mu \mathrm{m}$ mesh collections. All fish larvae were measured. Up to 5 specimens of the 5 most abundant species were selected from each of the 252 samples for gut content analysis.

Selectivity for a given prey was measured by comparing the frequency of this prey in the diet of the larvae with its frequency in the plankton. Chesson's electivity index for prey $j, \alpha_{\hat{\jmath}}$, was computed for each prey:

$$
\left.\alpha_{j}=\left(d_{j} / p_{j}\right) / \Sigma d_{1} / p_{1}\right), \text { for } i=1, \ldots, n(\text { Chesson 1978) (1) }
$$

where $n=$ number of prey items considered for a given fish species; $d_{j}$ and $p_{j}=$ frequencies of prey $j$ in the diet and in the plankton respectively; $d_{1}$ and $p_{z}=$ the same frequencies for the $i^{\text {th }}$ prey. Electivity for a given prey was first computed for each of the larvae examined, and then averaged for different length categories of larvae. Chesson's $\alpha$ is independent of the fluctuations in the absolute abundance of the plankton and varies only if the behaviour of the larvae changes (Pearre 1982). $\alpha$ is thus appropriate to describe ontogenetic variations in selectivity. Following Govoni et al. (1986a), only those prey items which contributed substantially $(>2 \%)$ to the diet of a given species at one stage of its development were considered in the analysis.

The resource available at depth $z$ for larvae of length category $1, R_{z l}$, was defined as

$$
R_{z l}=\sum A_{p z} V_{p l} F_{p l}, \text { for } p=1, \ldots, n
$$

where $n=$ number of different prey taxa found in the diet of a given fish species; $A_{p z}=$ abundance of the $p^{\text {th }}$ prey at depth $z ; V_{p l}=$ average volume $\left(\mathrm{mm}^{3}\right)$ of the $p^{\text {th }}$ prey in the gut of larvae of length category $l_{i} F_{p l}=$ frequency of the $p^{\text {th }}$ prey in the gut of larvae of length category $1 . F_{p l}$ is used as an index of the availability of prey $p$ for the larvae of length category $l$.

The resource consumed daily by each species at depth $z$ was estimated as follows. First, the average daily ration for larvae of length category $l, D R_{l}$ was computed:

$$
D R_{l}=3.2 \Sigma V_{p l} N_{p l}, \text { for } p=1, \ldots, n
$$

where $N_{p l}=$ average number of prey $p$ in the gut of larvae of length category 1 . The constant 3.2 represents the number of gut fillings for a feeding period of $14 \mathrm{~h}$ per day, and is given by $1+14 / H$, where $H$ is the stomach evacuation time (Beyer \& Laurence 1980). The 34 estimates of $H$ for complete digestion in marine fish larvae listed in Theilacker \& Dorsey (1980), Pedersen (1984), and Govoni et al. (1986b) range from 1 to $24 \mathrm{~h}$, with an average of $6.5 \mathrm{~h}$. For each sample, $D R_{l}$ was multiplied by the number of larvae in length category 1 , and this product was summed over the different length categories. The average daily consumption of resource at depth $z$ was obtained by averaging the resulting sum over the 21 vertical profiles.

Correlation and other measures of dependence are adequate statistics to compare the vertical distribution of organisms sampled with nets or pumps (Venrick 1986). However, the parametric testing of these statistics is often invalid for 2 reasons: the plankton samples are not independently collected in time or space, and the abundance of the 2 taxa considered is estimated from the same collection. In this study, correlation coefficients (Pearsons $r$ ) between the vertical distribution of the larvae and their resource were tested for significance by a non-parametric randomization procedure ('bootstrap' approach). First, the actual correlation $\left(r_{a}\right)$ between the percentage of the resource at depth and the percentage of the larvae at depth was computed. Second, the percentages of the larvae at depth were shuffled using a uniform random number generator (subroutine GGPER of the International Mathematical and Statistical Library) and a new correlation coefficient $r_{r}$ was computed. This value of $r_{r}$ represented one possible outcome of the correlation analysis when the larvae are randomly distributed relative to the unvarying distribution of their resource. This second step was repeated 2000 times to establish the frequency distribution of $r_{r}$. Finally, $r_{a}$ was tested against the frequency distribution of $r_{r}$ to determine the probability of observing a correlation greater or equal to $r_{a}$ by chance.

\section{RESULTS}

\section{Temperature, chlorophyll, and zooplankton}

During our sampling, temperature differences between surface and bottom ranged from 0.6 to $1.2^{\circ} \mathrm{C}$, and thermal gradients never exceeded $0.13^{\circ} \mathrm{C} \mathrm{m} \mathrm{m}^{-1}$ (Fig. 2). The water column was nearly isothermal at the beginning of sampling. After $60 \mathrm{~h}$, a weak stratification had developed near the surface.

The phytoplankton assemblage was typical of a postspring-bloom situation with biomass made up mainly of large diatoms and dinoflagellates (Table 1). Initially, 
chlorophyll a was evenly distributed in the water column (Fig. 2). Its subsequent accumulation at depth reflected the sinking of phytoplankton cells.

Given their volume, copepods dominated the zooplankton biomass (Table 1). On average, their abundance increased by a factor of ca 7 from surface to bottom (Fig. 3). This pattern varied little during the $60 \mathrm{~h}$ of sampling and no mass migration to the surface was observed at night. The vertical distribution of copepod eggs followed that of adult copepods, whereas copepod nauplii were more uniformly distributed (Fig. 3). Cladocerans were abundant (Table 1) and distributed in the shallow half of the water column (Fig. 3). The abundance of these 4 taxa was consistently greater in night-time collections than in daytime collections. Depth-integrated differences in abundance between night and day represented 13.5, 17.2, 24.0, and 35.2\% of night-time total abundance for copepods, copepod nauplii, copepod eggs and cladocerans respectively.

\section{Ichthyoplankton composition and length distribution}

The ichthyoplankton assemblage was typical of the coastal waters of the Channel in May (Russell 1976). With more than 500 and 100 larvae per $100 \mathrm{~m}^{3}$ respectively, sprat Sprattus sprattus and dragonnet Callyonimus lyra dominated numerically (Table 1). Thickback sole Microchirus variegatus, topknot Phrynorhombus norvegicus, and whiting Merlangius merlangus were less abundant but regularly captured in the samples. Several other species were captured frequently but were judged too scarce to warrant detailed analysis.

With the exception of Sprattus sprattus, the size frequency distribution of the larvae collected in daytime did not differ significantly from that of the larvae col-

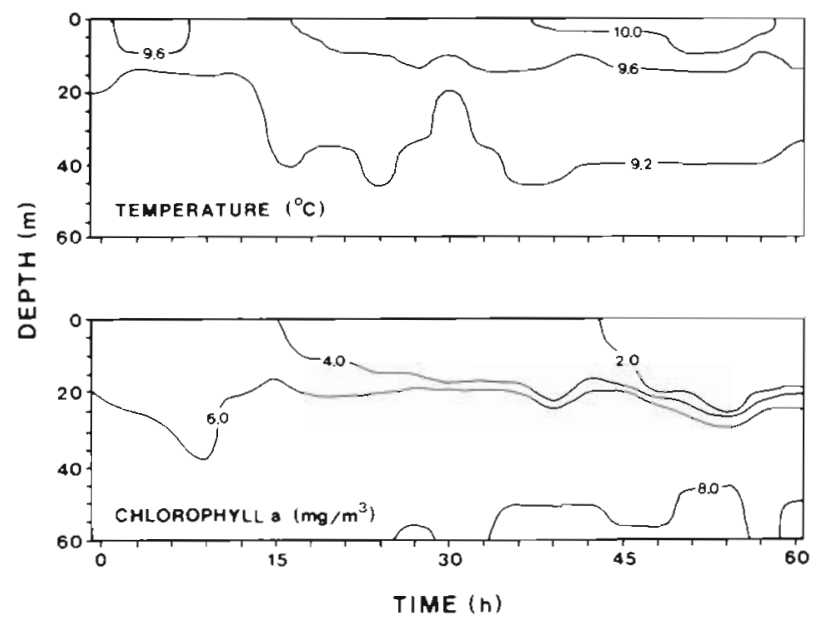

Fig. 2. Time-depth plots of temperature and chlorophyll a concentration for the $60 \mathrm{~h}$ of sampling starting at 18:00 h (BST) on 18 May 1983 lected at night (Kolmogorov-Smirnov test, $D_{\max }$ $\leq 0.080, p \geq 0.163$ ) suggesting little avoidance of the pump intake (Fig. 4). Significant daytime avoidance was observed in sprat longer than $6 \mathrm{~mm}\left(D_{\max }=0.216\right.$, $p<0.001$ )

\section{Feeding rhythms, diet, and prey electivity}

To investigate ontogenetic trends in the dynamics of the early fish, the larvae of the 5 most abundant species were divided into 4 length categories (Table 2). The smallest length category of each species was comprised mostly of yolksac larvae.

Feeding incidence was above $50 \%$ in all species

Table 1. Average density of the dominant planktonic taxa

$$
(n=252)
$$

Phytoplankton
Diatoms
Dinoflagellates
Flagellates
Haptophycae (Phaeocystis)
Zooplankton
Copepods
Oithona sp.
Pseudocalanus elongatus
Temora longicornis
Acartia sp.
Paracalanus parvis
Oncaea subtilis
Calanus helgolandicus
Oncaea sp.
Copepod eggs
Copepod nauplii
Cladocerans
Evadne nordmanni
Podon intermedius
Others
Oikopleura sp.
Cypris larvae
Lamellibranch larvae
Polychaete larvae
Planktonic predators
Chaetognaths
Cnidaria
Annelidae
lchthyoplankton
Sprattus sprattus
Callyonimus lyra
Microchirus variegatus
Phrynorhombus norvegicus
Merlangius merlangus
Trisopterus spp.
Microstomus kitt
Gobiidae
Zeugopterus punctatus
Serranidae
Arnodytidae
Others

(no. $\mathrm{ml}^{-1}$ ) 320

4

3880

2710

(no. $\mathrm{m}^{-3}$ )

3040.0

841.5

439.3

437.1

178.1

115.0

79.0

39.5

2401.0

7918.8

1903.5

272.2

613.8

99.0

53.7

44.4

(no. $100 \mathrm{~m}^{-3}$ ) 207.2

108.5

6.3

(no. $100 \mathrm{~m}^{-3}$ ) 557.4

113.7

18.4

14.4

6.3

3.9

3.7

1.8

1.0

0.8

0.5

0.3 


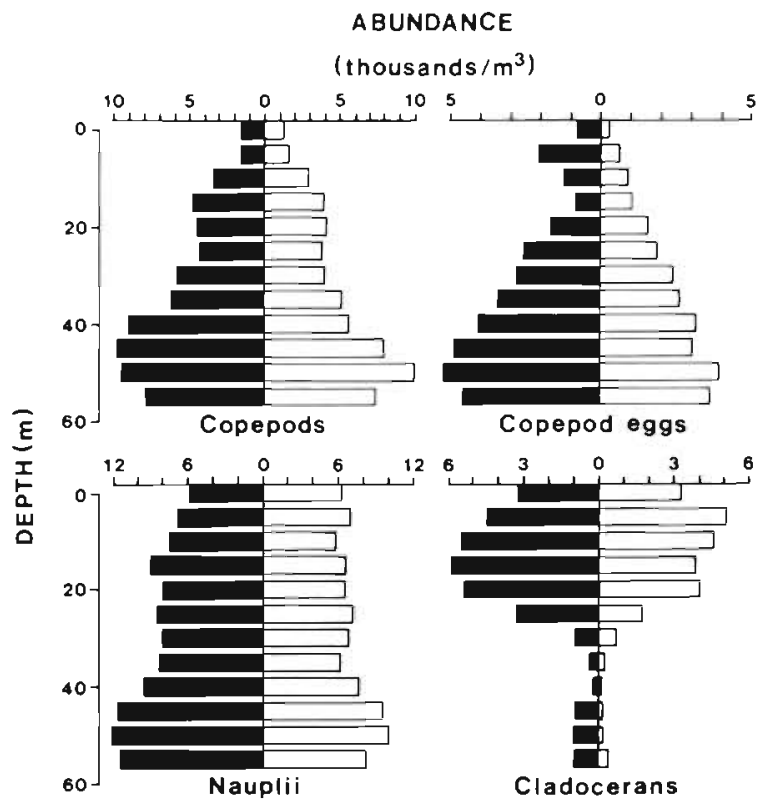

Fig. 3. Average vertical profile of abundance by night (black histograms, average of 9 profiles) and by day (open histograms, average of 12 profiles) for copepods (copepodites + adults), copepod eggs, copepod nauplii, and cladocerans (Evadne nordmanni + Podon intermedius)

except Sprattus sprattus (Table 2). The very low percentages observed for $S$. sprattus suggested regurgitation and/or defecation following capture by the pump or fixation. In the other species, feeding incidence increased regularly with length. The average number of prey per larva also increased with length except for Microchirus variegatus (Table 2). Judging from the relatively low average number of prey found in its gut, $M$. variegatus appeared a less active feeder than the other species.

Diel rhythms were evident in the feeding activity of the larvae. Generally, the average number of prey in the gut increased during the day, reached a maximum around sunset, decreased during the night, and reached a minimum around dawn (Fig. 5). This pattern, typical of visual planktivores, was best defined in Callyonimus lyra and Microchirus variegatus. In Merlangius merlangus and Phrynorhombus norvegicus, the average number of prey per larva was higher and varied more erratically (Fig. 5). Maximum values were often reached after sunset for these species, suggesting that some feeding took place early in the night.

The small number (15) of prey found in the gut of the 1004 sprat larvae examined was comprised primarily of copepod nauplii and copepodites (87\%). This is consistent with the diet reported by Last (1980) for the coastal waters of the North Sea. Since our data were insufficient to describe ontogenetic changes in the diet of sprat, further analysis was based on the more complete data set supplied by Last.

Fish larvae fed primarily on the developmental stages of copepods, except Microchirus variegatus which exploited a wide range of non-copepod prey (Table 3). With increasing length, the diet of species specializing on copepods shifted from the small

Table 2. Capture and feeding statistics of larval fish by species and length classes

\begin{tabular}{|c|c|c|c|c|c|}
\hline Species & $\begin{array}{l}\text { Length class } \\
(\mathrm{mm})\end{array}$ & No. captured & $\begin{array}{l}\text { No. examined } \\
\text { for gut content }\end{array}$ & Percent with prey & $\begin{array}{l}\text { Average no. } \\
\text { of prey in gut }\end{array}$ \\
\hline Callyonimus lyra & $\begin{array}{c}<3 \\
3 \text { to }<4 \\
4 \text { to }<5 \\
\geq 5\end{array}$ & $\begin{array}{r}5151 \\
892 \\
268 \\
186\end{array}$ & $\begin{array}{r}602 \\
292 \\
96 \\
49\end{array}$ & $\begin{array}{l}50.1 \\
61.0 \\
71.9 \\
74.0\end{array}$ & $\begin{array}{l}0.80 \\
1.13 \\
1.82 \\
2.62\end{array}$ \\
\hline $\begin{array}{l}\text { Merlangius } \\
\text { merlangus }\end{array}$ & $\begin{array}{c}<4 \\
4 \text { to }<5 \\
5 \text { to }<6 \\
\geq 6\end{array}$ & $\begin{array}{r}181 \\
93 \\
48 \\
37\end{array}$ & $\begin{array}{r}163 \\
72 \\
40 \\
31\end{array}$ & $\begin{array}{l}33.3 \\
65.4 \\
78.3 \\
62.9\end{array}$ & $\begin{array}{l}0.85 \\
2.89 \\
4.91 \\
3.29\end{array}$ \\
\hline $\begin{array}{l}\text { Phrynorhombus } \\
\text { norvegicus }\end{array}$ & $\begin{array}{c}<4 \\
4 \text { to }<5 \\
5 \text { to }<6 \\
\geq 6\end{array}$ & $\begin{array}{r}469 \\
237 \\
73 \\
45\end{array}$ & $\begin{array}{r}183 \\
147 \\
55 \\
40\end{array}$ & $\begin{array}{l}62.5 \\
85.3 \\
87.8 \\
88.6\end{array}$ & $\begin{array}{l}1.69 \\
3.73 \\
4.63 \\
5.43\end{array}$ \\
\hline $\begin{array}{l}\text { Sprattus } \\
\text { sprattus }\end{array}$ & $\begin{array}{c}<5 \\
5 \text { to }<7 \\
7 \text { to }<9 \\
\geq 9\end{array}$ & $\begin{array}{r}25383 \\
3524 \\
1768 \\
1185\end{array}$ & $\begin{array}{l}622 \\
155 \\
124 \\
103\end{array}$ & $\begin{array}{l}0.0 \\
3.9 \\
1.6 \\
3.9\end{array}$ & $\begin{array}{l}- \\
- \\
- \\
-\end{array}$ \\
\hline $\begin{array}{l}\text { Microchirus } \\
\text { variegatus }\end{array}$ & $\begin{array}{c}<4 \\
4 \text { to }<5 \\
5 \text { to }<6 \\
\geq 6\end{array}$ & $\begin{array}{r}694 \\
202 \\
106 \\
51\end{array}$ & $\begin{array}{r}410 \\
163 \\
98 \\
45\end{array}$ & $\begin{array}{l}55.0 \\
57.1 \\
67.3 \\
80.0\end{array}$ & $\begin{array}{l}1.15 \\
1.04 \\
1.11 \\
1.58\end{array}$ \\
\hline
\end{tabular}


copepod eggs and nauplii to the larger copepodites (Table 3).

All species fed selectively at all lengths, but selectivity for a given prey changed during ontogeny (Table 4). Selection for copepod nauplii was particularly strong in the early stages of species specializing on copepods. This preference for nauplii decreased regularly with length as the diet shifted to larger prey. Interestingly, each fish species specialized on a different copepod species and selected more and more strongly for it as length increased (Table 4). Callyonimus lyra, Merlangius merlangus, and Phrynorhombus norvegicus selected for Calanus helgolandicus, Pseudocalanus elongatus, and Acartia sp. respectively. Assuming a diet similar to that reported by Last (1980). Sprattus sprattus selected for Paracalanus parvus. Small Mi-
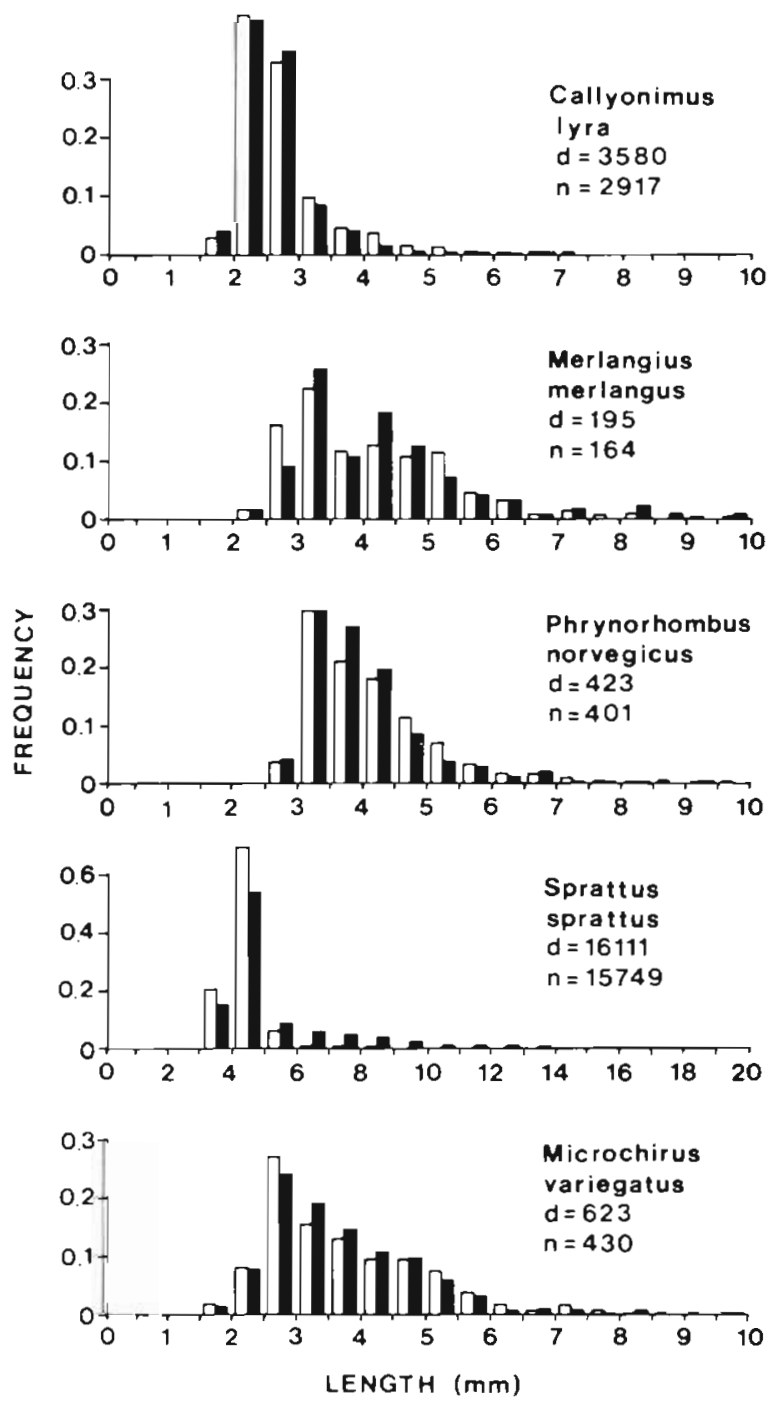

Fig. 4. Size frequency distributions of fish captured by night (black histograms) and by day (open histograms). Sample sizes given for day (d) and nught (n). Note the different scales for Sprattus sprattus crochirus variegatus selected weakly but significantly for a wide range of prey (Table 4). With increasing size, active selection by $M$. variegatus became restricted to polychaete larvae, the cladoceran Evadne nordmanni, and Temora longicornis.

\section{Ontogenetic migrations and vertical distribution of predators and resource}

The vertical distribution of fish larvae varied little over the diel cycle but changed considerably during ontogeny (Fig. 6). The yolksac larvae of all species concentrated above $30 \mathrm{~m}$. This pattern remained similar by day and by night save for a slight deepening of the centre of mass of the distribution either at night (Callyonimus lyra, Merlangius merlangus, and Sprattus sprattus) or in daytime (Microchirus variegatus). With increasing size, the postlarvae of all species moved progressively deeper in the water col-
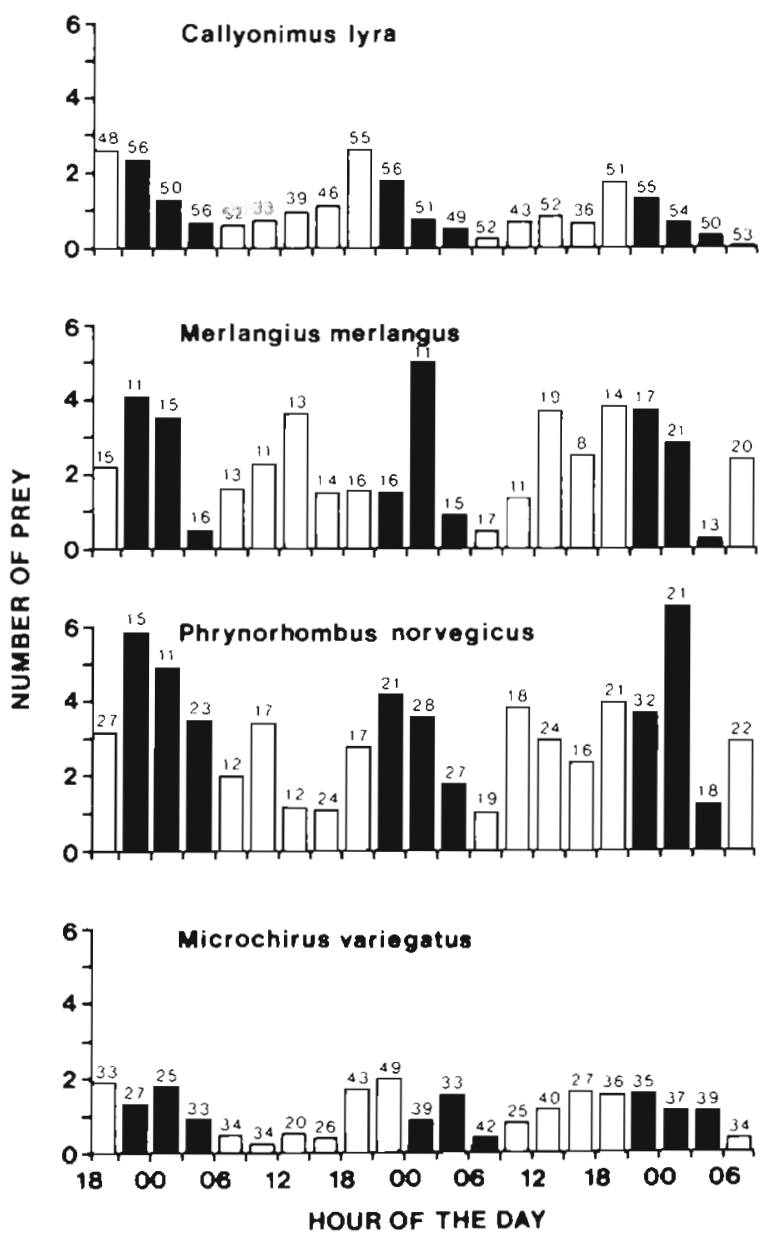

Fig. 5. Feeding rhythms of fish larvae: average number of prey in the gut as a function of time. Black histograms: night; open histograms: day. Number of larvae involved in the average is given above each histogram 
umn. C. lyra and $M$. merlangus tended to accumulate at depth, whereas Phrynorhombus norvegicus and $S$. sprattus became more uniformly distributed. $M$. variegatus quickly acquired the characteristics of the demersal form (e.g. loss of bilateral symmetry, migration of eye), and moved rapidly to deeper levels. With increasing size, day-night differences in vertical distribution tended to develop, particularly in $M$. variegatus (Fig. 6). In general however, the circadian migrations were weak and did not mask the more prominent ontogenetic migrations.

Chaetognaths, the most abundant planktonic predator captured by the pump (Table 1), were concentrated at depth in daytime and more uniformly distributed in the water column at night (Fig. 7). Pelagic Cnidaria (mainly Obelia sp., Steenstrupia rubra, and Bougainvillea sp.) were also concentrated at depth with a tendency to move slightly higher in the water column at night (Fig. 7).

Yolksac larvae were concentrated above $30 \mathrm{~m}$ (Fig. 6) in the section of the water column where planktonic predators were the least abundant. With increasing size, the overlap between the distribution of the larvae and that of the predators increased as the former descended in the water column (Table 5).
The resource available to larvae feeding primarily on copepods (Callyonimus lyra, Merlangius merlangus, Phrynorhombus norvegicus and Sprattus sprattus) was invariably more abundant at depth (Fig. 8). Since the vertical distribution of the different prey differed, ontogenetic variations of the diet translated into noticeable variations in the vertical distribution of the resource available to larvae of different length (Fig. 8). At the beginning of the ontogeny, the vertical distribution of yolksac larvae was unrelated to the distribution. of their resource. The ontogenetic migrations of the postlarvae resulted in the progressive adjustment of their vertical distribution to the vertical distribution of their resource. The clearest response was observed when the gradient in resource was relatively steep $/ C$. lyra, M. merlangus). Species facing a more uniform distribution of their resource tended to spread evenly in the water column ( $P$. norvegicus, $S$. sprattus). In all cases, the vertical gradient in resource existed before the larvae undertook their ontogenetic migration (Fig. 8).

The resource of Microchirus variegatus, which fed primarily on non-copepod prey, was always more abundant in the surface layer. The ontogenetic migration of this species was unrelated to the vertical dis-

Table 3. Percent composition of larval fish diet by species and length classes. Number of larvae examined for each length class is given in Table 2. The diet of Sprattus sprattus is based on the data set given by Last (1980)

\begin{tabular}{|c|c|c|c|c|c|}
\hline Species & $\begin{array}{l}\text { Length class } \\
(\mathrm{mm})\end{array}$ & $\begin{array}{l}\text { Copepod } \\
\text { eggs }\end{array}$ & $\begin{array}{l}\text { Copepod } \\
\text { nauplii }\end{array}$ & $\begin{array}{c}\text { Copepod } \\
\text { copepodites }^{a}\end{array}$ & $\begin{array}{l}\text { Non- } \\
\text { copepod }^{b}\end{array}$ \\
\hline Calyonimus lyra & $\begin{array}{c}<3 \\
3 \text { to }<4 \\
4 \text { to }<5 \\
\geq 5\end{array}$ & $\begin{array}{r}3 \\
12 \\
25 \\
35\end{array}$ & $\begin{array}{r}77 \\
45 \\
11 \\
9\end{array}$ & $\begin{array}{l}12 \\
31 \\
51 \\
46\end{array}$ & $\begin{array}{r}8 \\
12 \\
13 \\
10\end{array}$ \\
\hline $\begin{array}{l}\text { Merlangius } \\
\text { merlangus }\end{array}$ & $\begin{array}{c}<4 \\
4 \text { to }<5 \\
5 \text { to }<6 \\
\geq 6\end{array}$ & $\begin{array}{l}3 \\
0 \\
5 \\
7\end{array}$ & $\begin{array}{l}96 \\
96 \\
78 \\
61\end{array}$ & $\begin{array}{r}1 \\
4 \\
16 \\
29\end{array}$ & $\begin{array}{l}0 \\
0 \\
1 \\
3\end{array}$ \\
\hline $\begin{array}{l}\text { Phrynorhombus } \\
\text { norvegicus }\end{array}$ & $\begin{array}{c}<4 \\
4 \text { to }<5 \\
5 \text { to }<6 \\
\geq 6\end{array}$ & $\begin{array}{r}3 \\
3 \\
2 \\
11\end{array}$ & $\begin{array}{l}95 \\
83 \\
68 \\
25\end{array}$ & $\begin{array}{r}2 \\
14 \\
30 \\
61\end{array}$ & $\begin{array}{l}0 \\
0 \\
0 \\
3\end{array}$ \\
\hline $\begin{array}{l}\text { Sprattus } \\
\text { sprattus }\end{array}$ & $\begin{array}{c}<5 \\
5 \text { to }<7 \\
7 \text { to }<9 \\
\geq 9\end{array}$ & $\begin{array}{l}0 \\
0 \\
4 \\
6\end{array}$ & $\begin{array}{l}56 \\
67 \\
71 \\
20\end{array}$ & $\begin{array}{r}0 \\
0 \\
26 \\
74\end{array}$ & $\begin{array}{r}44 \\
33 \\
0 \\
0\end{array}$ \\
\hline $\begin{array}{l}\text { Microchirus } \\
\text { variegatus }\end{array}$ & $\begin{array}{c}<4 \\
4 \text { to }<5 \\
5 \text { to }<6 \\
\geq 6\end{array}$ & $\begin{array}{c}24 \\
23 \\
11 \\
3\end{array}$ & $\begin{array}{l}0 \\
0 \\
0 \\
0\end{array}$ & $\begin{array}{r}5 \\
6 \\
9 \\
17\end{array}$ & $\begin{array}{l}71 \\
70 \\
78 \\
80\end{array}$ \\
\hline
\end{tabular}




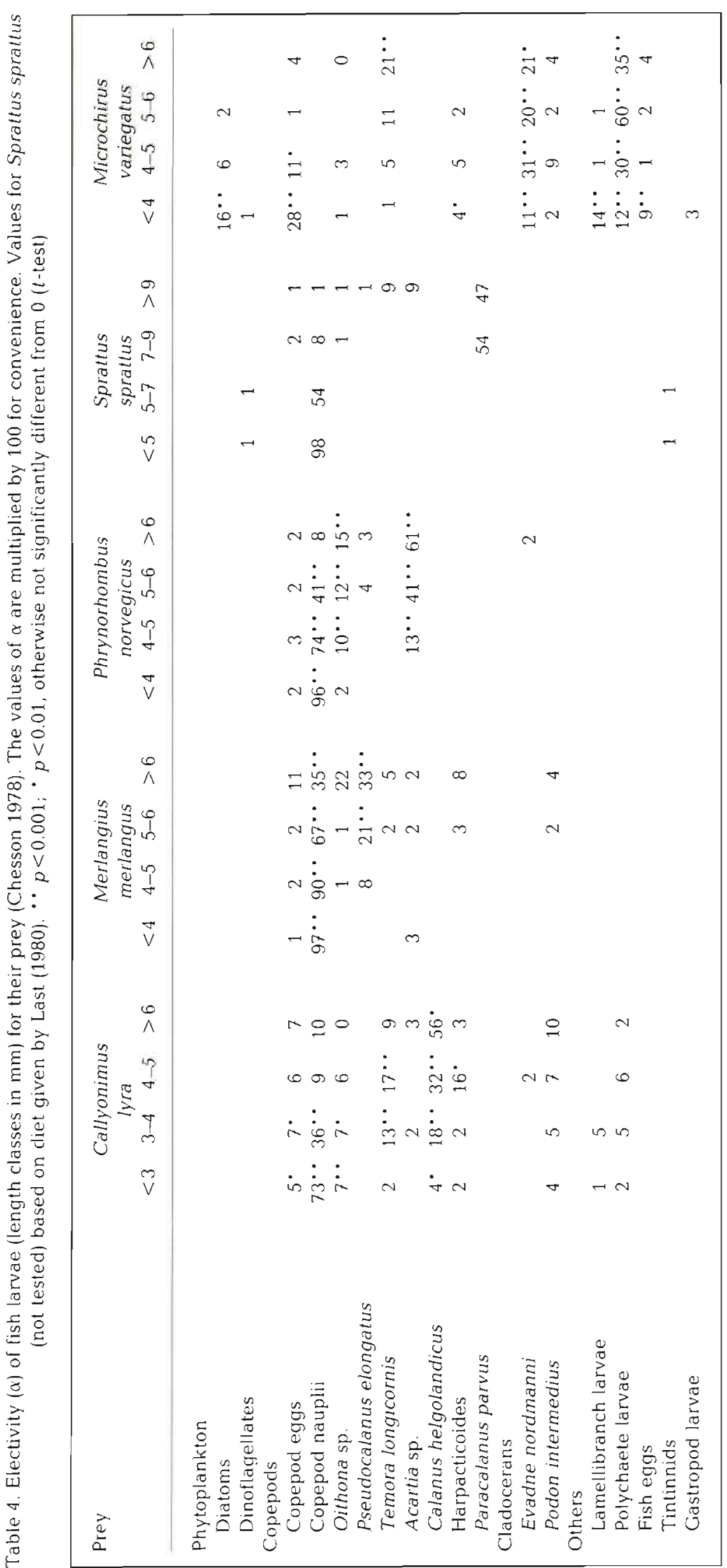


tribution of its resource but appeared linked to its rapid metamorphosis into the demersal form.

\section{Food consumption and food supply}

The resource consumed daily by fish larvae specializing on copepods and the total resource available to these species were compared. Calculations of the total resource available was based on the abundance of the 14 most frequent prey items in the pooled diet of the 4 species.

The volume of the resource consumed by a given species per cubic metre of water $\left(\mathrm{mm}^{3} \mathrm{~m}^{-3}\right)$ depended on its abundance (Table 1) and, to a lesser degree, its voracity (Table 2 ). For example, the less voracious but more abundant Callyonimus lyra consumed a greater volume of resource than Merlangius merlangus (Table 6). Within a species, vertical gradients in the volume of the resource consumed reflected ontogenetic changes in prey size and ontogenetic migrations. In $C$. lyra, for example, a first maximum at $20 \mathrm{~m}$ was due to the concentration at that depth of the numerous small larvae, whereas a secondary peak near the bottom represented the consumption of large prey by the older, epibenthic stages (Table 6).

The depth-integrated volume of food consumed daily by individual species of fish larvae feeding primarily on copepods ranged from 0.037 to $0.507 \mathrm{~mm}^{3} \mathrm{~m}^{-3}$ (Table 6) and represented less than $0.6 \%$ of the standing biomass available to them. Total daily consumption by the 4 species represented about $1 \%$ of the available resource (Table 6).

\section{DISCUSSION}

\section{Predator avoidance or predation?}

Inverse distributions of fish larvae and planktonic predators have often been interpreted as reflecting a reduction of larval fish numbers by predation. A recent review indicated however that the alternative interpretation of predator avoidance, either behaviourally or as
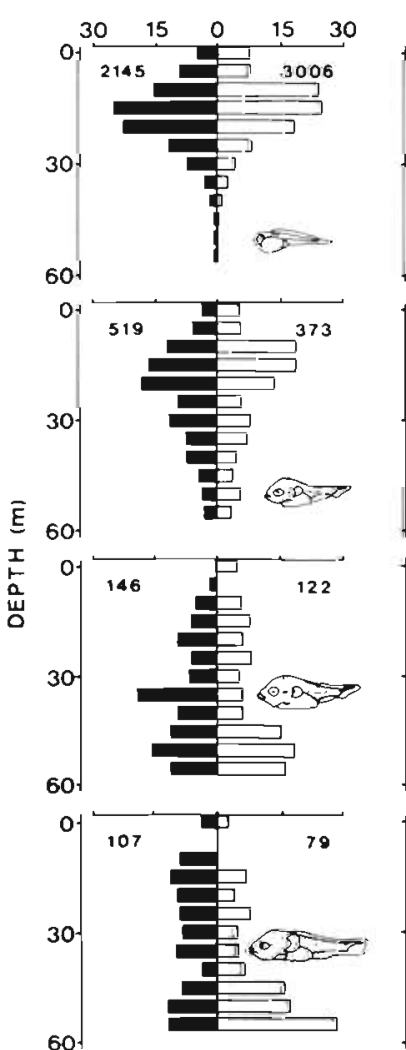

Callyonimus lyra
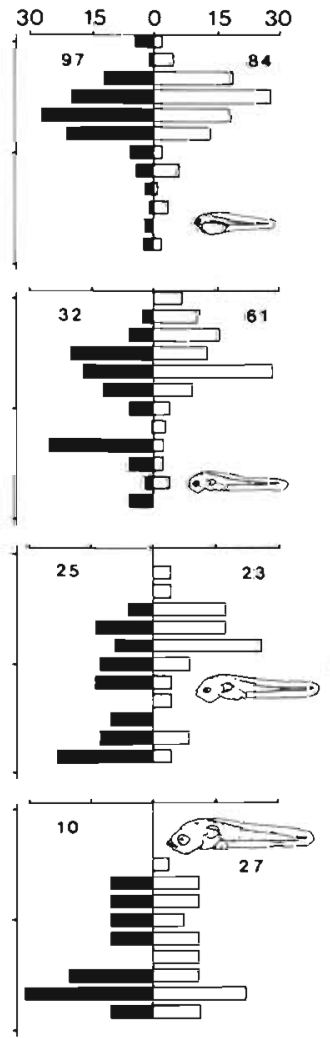

Merlangius merlangus
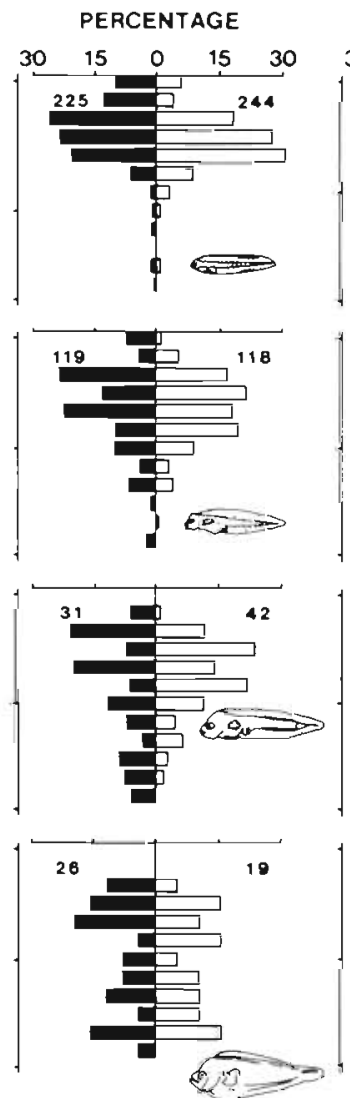

Phrynorhombus norvegicus
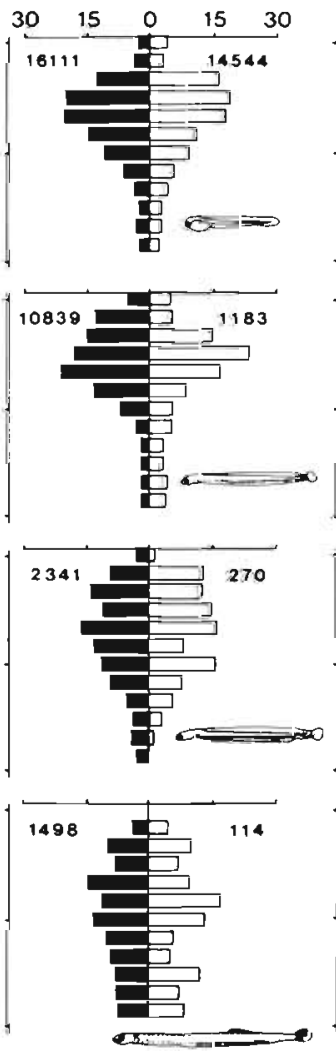

Sprattus sprattus
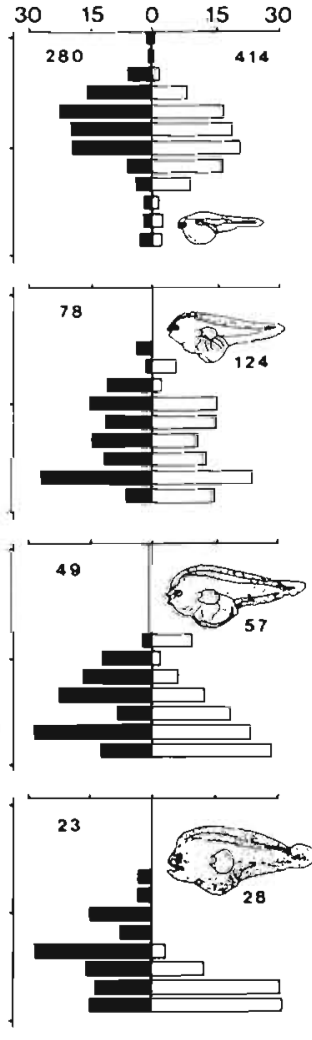

Microchirus variegatus

Fig. 6. Percent vertical distribution of fish larvae by night (black histograms) and by day (open histograms) by length classes. Values are the average of the percentages at depth for each of the 21 profiles. Numbers indicate the sample size (total number of larvae captured) for day or night. Length classes as in Table 2. Outline of larvae at length after Russell (1976) 
Table 5. Percent overiap between the vertical distribution of fish larvae and the vertical distribution of planktonic predators

\begin{tabular}{lccc}
\hline Species & $\begin{array}{c}\text { Length class } \\
(\mathrm{mm})\end{array}$ & $\begin{array}{c}\text { Percent overlap } \\
\text { with chaetognaths }\end{array}$ & $\begin{array}{c}\text { Percent overlap } \\
\text { with medusae }\end{array}$ \\
\hline Callyonimus lyra & $<3$ & 40.4 & 22.7 \\
& 3 to $<4$ & 60.4 & 45.3 \\
& 4 to $<5$ & 87.6 & 75.0 \\
Merlangius & $\geq 5$ & 83.2 & 78.6 \\
merlangus & $<4$ & 42.1 & 26.9 \\
& 4 to $<5$ & 53.9 & 35.1 \\
Phrynorhombus & 5 to $<6$ & 61.9 & 58.3 \\
norvegicus & $\geq 6$ & 74.9 & 73.7 \\
& $<4$ & 34.1 & 16.4 \\
Sprattus & 4 to $<5$ & 45.4 & 30.9 \\
sprattus & 5 to $<6$ & 52.3 & 42.8 \\
& $\geq 6$ & 70.1 & 59.3 \\
Microchirus & $<5$ & 51.9 & 38.5 \\
variegatus & 5 to $<7$ & 51.4 & 33.7 \\
& 7 to $<9$ & 54.5 & 41.7 \\
& $\geq 9$ & 71.2 & 60.3 \\
& $<4$ & 47.7 & 43.5 \\
& 4 to $<5$ & 74.8 & 72.9 \\
& 5 to $<6$ & 75.2 & 77.8 \\
& $\geq 6$ & 67.7 & 77.3 \\
\hline
\end{tabular}

a result of adapted dispersion strategies, is often more adequate (Frank \& Leggett 1985). In this study, an inverse vertical distribution was observed between yolksac fish larvae and planktonic predators such as chaetognaths and pelagic Cnidaria. Chaetognaths

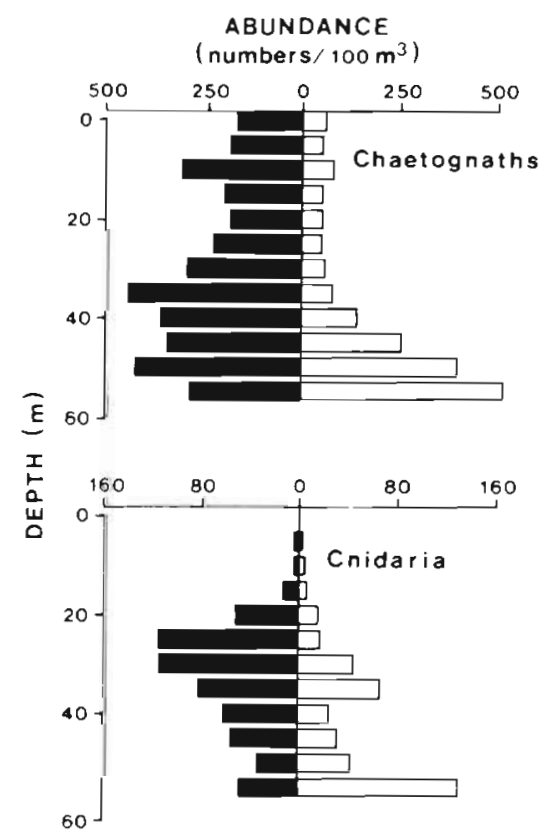

Fig. 7. Average vertical profile of planktonic predators abundance by night (black histograms, average of 9 profiles) and by day (open histograms, average of 12 profiles) ingest fish larvae when starved in the laboratory (Kuhlmann 1977) but otherwise feed almost exclusively on copepods (Kuhlmann 1977, Øresland 1987). Pelagic Cnidaria (jellyfish) are perhaps the most important planktonic predators of yolksac fish larvae (Hunter 1984, Möller 1984, Purcell 1985, Purcell et al. 1987). The species captured in this study are known to prey on fish larvae but feed primarily on copepods (Lebour 1923, Aray \& Hay 1982). Pelagic Cnidaria concentrated in the deep half of the water column, where copepods were the most abundant. It is plausible that nektonic planktivores (e.g. juvenile and adult fishes) which were not captured by the pump but are potential predators of fish larvae, also concentrated where the bulk of the zooplankton biomass was found.

The relatively higher abundance of yolksac fish larvae in the shallow half of the water column (Fig. 6) resulted either from their avoidance of predators or from a reduction of their number at depth by predation. Since no direct estimate of predation rate at depth was obtained, the 2 possibilities cannot be distinguished with certainty. However, Cnidaria were relatively sparse $\left(1.1 \mathrm{~m}^{-3}\right.$ on average) and their preferred alternate prey (copepods) outnumbered yolksac larvae by a factor of ca $700\left(5170 \mathrm{~m}^{-3}\right.$ versus $7.2 \mathrm{~m}^{-3}$ on average $)$. Given this abundance of alternate preferred prey, planktonic Cnidaria (or nektonic planktivores) probably had little impact on the abundance of fish larvae as suggested by recent experimental work (Brownell 1985) and modelisation (Pepin 1987). Thus, the scarcity 
Table 6. Daily consumption of resource $\left(\mathrm{mm}^{3} \mathrm{~m}^{-3}\right)$ at depth by species feeding primarily on copepods, total consumption, and resource available to these species. Calculations for Sprattus sprattus based on data supplied by Last (1980)

\begin{tabular}{|c|c|c|c|c|c|c|}
\hline $\begin{array}{l}\text { Depth } \\
\text { (m) }\end{array}$ & $\begin{array}{c}\text { Callyonimus } \\
\text { lyra }\end{array}$ & $\begin{array}{l}\text { Merlangius } \\
\text { merlangus }\end{array}$ & $\begin{array}{c}\text { Phrynorhombus } \\
\text { norvegicus }\end{array}$ & $\begin{array}{l}\text { Sprattus } \\
\text { sprattus }\end{array}$ & Total & $\begin{array}{l}\text { Resource } \\
\text { available }\end{array}$ \\
\hline 2 & 0.023 & 0.002 & 0.001 & 0.004 & 0.030 & 5.85 \\
\hline 5 & 0.014 & 0.001 & 0.002 & 0.013 & 0.030 & 6.67 \\
\hline 10 & 0.040 & 0.001 & 0.016 & 0.028 & 0.085 & 6.36 \\
\hline 15 & 0.058 & 0.004 & 0.022 & 0.028 & 0.112 & 7.53 \\
\hline 20 & 0.070 & 0.006 & 0.023 & 0.035 & 0.135 & 7.06 \\
\hline 25 & 0.035 & 0.005 & 0.015 & 0.026 & 0.081 & 7.48 \\
\hline 30 & 0.038 & 0.001 & 0.010 & 0.026 & 0.075 & 7.21 \\
\hline 35 & 0.036 & 0.003 & 0.010 & 0.019 & 0.068 & 6.99 \\
\hline 40 & 0.032 & 0.002 & 0.012 & 0.013 & 0.060 & 8.39 \\
\hline 45 & 0.038 & 0.003 & 0.007 & 0.014 & 0.062 & 10.25 \\
\hline 50 & 0.062 & 0.006 & 0.014 & 0.012 & 0.094 & 10.67 \\
\hline 55 & 0.062 & 0.004 & 0.002 & 0.012 & 0.080 & 9.43 \\
\hline Total & 0.507 & 0.037 & 0.134 & 0.230 & 0.911 & 93.89 \\
\hline
\end{tabular}

of prolarval fish at depth is unlikely to have resulted directly from predation.

As discussed above, predation pressure on fish larvae was probably low given the availability of prefer- red alternate prey. With the concentration of planktonic (and perhaps nektonic) predators at depth, the predation risk for an individual yolksac larva was nevertheless relatively higher in the deep half of the
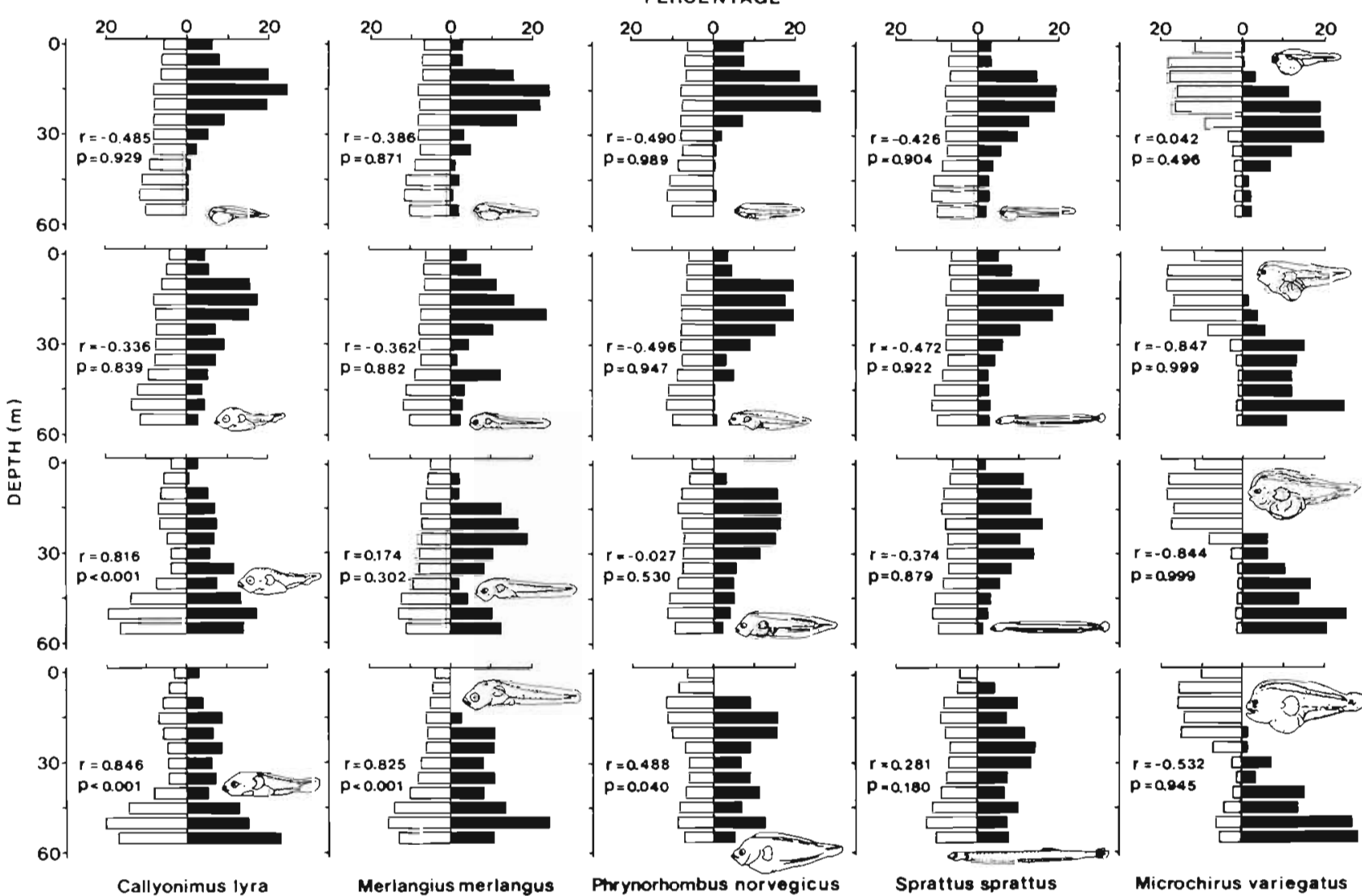

Fig. 8. Percent vertical distribution of fish larvae (black histograms) and their resource (open histograms) by length classes. Values are averages of the percentages at depth for each of the 21 profiles. Length classes as in Table 2. Outline of larvae at length after Russell (1976) 
water column. Accordingly, yolksac larvae were concentrated in the shallow half of the water column. With increasing size, postlarvae which are less susceptible to predation descended in the water column, their distribution overlapping with that of other planktonic predators (Table 5). These observations are consistent with our hypothesis that ontogenetic migrations in fish larvae are related to ontogenetic changes in their susceptibility to predation.

\section{Optimal foraging by marine fish larvae}

The ontogenetic migrations of fish postlarvae specializing on copepods resulted in the progressive adjustment of their vertical distribution to the vertical distribution of their resource. With increasing size, the percentage of the larvae found at a given depth became proportional to the percentage of the resource available at that depth, as predicted by the Ideal Free Distribution model. Thus, the hypothesis that these species were optimizing their feeding strategy cannot be rejected. It could be argued that the causal relationships are confounded in this interpretation, and that the postlarvae did not seek out their prey but simply fed on the organisms that happened to be at the depth they moved to. However, for each of these species, the vertical gradient in the resource available existed before the larvae adjusted their distribution to it (Fig. 8). Therefore, ontogenetic changes in diet preceded the vertical migrations and cannot be interpreted as a consequence of these migrations. Furthermore, the larvae of each species did not simply feed on the organisms that happened to be available at depth but rather selected strongly for a given type of prey (Table 4). Finally, the ontogenetic changes in diet reported here reflected a shift from small copepod eggs and nauplii towards larger copepodites as larval size increased (Table 3). This shift in diet towards larger prey has been invariably reported in field studies of larval fish feeding (e.g. Last 1980, Kane 1984, Monteleone \& Peterson 1986, Schmitt 1986). In the laboratory, rearing experiments have demonstrated that increasingly larger prey are needed for survival (see Theilacker \& Dorsey 1980 for a review). Thus, the shift in diet observed in the present study cannot be attributed simply to changes in prey availability following vertical migrations.

Foraging behaviours by fish conforming to or supporting the predictions of the Ideal Free Distribution model (Fretwell \& Lucas 1970) have been observed under controlled conditions in the laboratory (Milinski 1979, Godin \& Keenleyside 1984) as well as in nature (Fraser \& Sise 1980, Power 1984). A first assumption of the IFD model is that foragers have free access to all sites. Temperature discontinuities can limit the migrations of planktonic organisms, but gradients of the magnitude observed in the present study $\left(<0.13^{\circ} \mathrm{C}\right.$ $\mathrm{m}^{-1}$ ) have little effect on plankton movements (Southward \& Barrett 1983). The presence of predators may also limit the distribution or movements of foragers (Gliwicz 1986, Milinski 1986). This was apparently the case for yolksac larvae which were distributed as a function of predator abundance rather than resource abundance. In postlarvae, the need to avoid planktonic predators either decreased rapidly with length (Bailey 1984, Hunter 1984, Brownell 1985, Folkvord \& Hunter 1986, Purcell et al. 1987) or was offset by the need to optimize foraging.

A second and central assumption of the IFD model is that local profitability decreases with increasing density of the foragers because of density-dependent competition. The Ideal Free Distribution achieved by the animals is a response to reduce the competition pressure and will develop only if density-dependent competition existed in the first place. In the present study, fish species that fed on copepods and potentially competed for their food with each other and with other planktonic predators achieved an Ideal Free Distribution. Microchirus variegatus, which fed on a noncopepod diet, showed no such response. When interpreted in the framework of the IFD model, these results suggest that density-dependent competition was sufficient to trigger a behavioural sharing of the resource among fish postlarvae and other planktonic predators of copepods.

A third assumption of the model is that foragers continuously monitor spatial variations in resource availability in order to select the most profitable site. Laboratory studies have demonstrated that fish larvae swim faster and in a more constant direction at low prey densities than at higher ones (Wyatt 1972, Hunter \& Thomas 1974, Munk \& Kiørboe 1985). If no densitydependent competition existed, this non-random search behaviour would result in the concentration of the post-larvae within the depth range of maximum prey abundance (Fig. 1a). The same search behaviour cued by local profitability (a function of prey and competitor densities) rather than local prey abundance. would lead to the distribution of the postlarvae in proportion to the percentage of the resource available at depth (Fig. 1b), as observed in species feeding on copepods (Fig. 8).

A final and somewhat unrealistic assumption of the original IFD model of Fretwell \& Lucas (1970) is that all competitors have equal competitive abilities. If this assumption is verified, the model predicts that every forager will receive the same individual payoff at equilibrium. Experimental studies have shown however that foragers of different competitive abilities neverthe- 
less achieved an Ideal Free Distribution (e.g. Godin \& Keenleyside 1984, Milinski 1987). The only evident consequence of unequal competitive abilities is that foragers received different payoffs. Thus, competitive abilities appear to have little importance in determining the distribution of the foragers. Milinski (1987) suggested that this assumption be deleted from the model.

\section{Other hypotheses}

The current paradigm on larval fish survival suggests that fish larvae seek to maximize their energy intake and growth rates in order to reduce the time during which they are prey to a large array of small, planktonic predators (e.g. Cushing 1974, Ware 1975). Our interpretation of larval fish distributions in the context of Optimal Foraging Theory assumes that fish larvae were trying to maximize their energy intake, and is thus consistent with this paradigm. Other hypotheses that do not invoke the argument of energy maximization could perhaps explain the observed distributions (e.g. time spent at a given depth is simply proportional to prey density at that depth). Nonetheless, we feel that because it is built on the tenet that foragers (i.e. fish postlarvae) seek to maximize their energy intake, OFT provides a more adequate conceptual framework than these hypotheses for the understanding of trophic relationships between fish larvae, their predators and their prey. Additional studies addressing the same and other predictions of the Optimal Foraging Theory are needed however to further confirm that early fish larvae are optimizing their feeding strategy in nature.

\section{Density-dependent competition and regulation of marine fish numbers}

The Malthusian view that the development of any population must be checked by some density-dependent mechanism, and the failure to detect such mechanisms in the adult phase, have led to the hypothesis that the density-dependent regulation of marine fish numbers takes place early in life (Jones 1973, Cushing 1974, Ware 1975, Shepherd \& Cushing 1980). Density-dependent competition for food is thought to reduce growth and increase the duration of the period during which the larvae are vulnerable to predators, thus leading to density-dependent mortality (Cushing 1974, Ware 1975). However, direct evidence for the existence of density-dependent competition for food in fish larvae is lacking (Ware 1975, Sissenwine 1984, Rothschild 1986, Taggart \& Leggett 1987). Further, estimates of the biomass consumed by fish larvae in the field indicate that individual species have little impact by themselves on the abundance of their prey (Cushing 1983, Dagg et al. 1984, Peterson \& Ausubel 1984, Monteleone \& Peterson 1986, Jenkins 1987). Our own estimates of the proportion of the available resource consumed by each species agree with this conclusion, and also show that the ichthyoplankton assemblage as a whole had little impact on the standing biomass of its resource (Table 6)

Paradoxically, when interpreted in the framework of the IFD model, the postlarval fish distributions observed in the present study suggest that density-dependent competition for food was actually strong enough to trigger some sharing of the resource available among fish postlarvae that fed on copepods. The specialization of the different fish species on different copepod species may represent further evidence of this sharing of the resource (Table 4). Since fish larvae appeared too dilute to have any significant impact on the abundance of their resource, other planktivores must have contributed to the generation of density-dependent competition for food. Studies have shown that invertebrate predators can be significant competitors of fish larvae feeding on copepods (e.g. Fraser 1970, Williams \& Collins 1985, Frank 1986). Copepod eggs and nauplii comprised $55 \%$ of the prey exploited by fish larvae. The greater abundance of copepod eggs and nauplii in night-time collections (Fig. 3) suggested that visual planktivores feeding in daytime reduced the abundance of the dominant food items of fish larvae by a factor of 17 to $24 \%$ daily. This is consistent with the more rigorous estimate of the impact of planktivores on the resource available to fish larvae by Dagg et al. (1984) who calculated that $18 \%$ of the production of nauplii were consumed daily by invertebrate predators. We conclude that if density-dependent competition for food was actually responsible for the development of an Ideal Free Distribution in fish postlarvae, this competition was generated at the level of the entire predator assemblage (including fish postlarvae) rather than at the intra- or interspecific level among fish postlarvae. This supports the hypothesis that the dynamics of invertebrate predators could play a central role in the density-dependent regulation of marine fish numbers during the larval and postlarval phase (Fraser 1970, Frank 1986).

In summary, the distribution of fish postlarvae feeding on copepods conformed to the predictions of the Ideal Free Distribution model. Hence, we cannot reject the hypothesis that these postlarvae were optimizing their foraging distribution in response to some densitydependent competition for food. It must be noted that other hypotheses could perhaps explain the observed distributions without invoking the arguments of energy maximization and density-dependent competition. These hypotheses are, however, at odds with the 
current paradigm that fish postlarvae must maximize growth to survive. If density-dependent competition actually occurred as suggested by the IFD model, our calculations of the impact of fish postlarvae on the abundance of their food indicate that this competition could not be generated at the intra- or interspecific levels within the ichthyoplankton assemblage. Density-dependent interactions with other planktonic predators must be called forth to explain the development of an Ideal Free Distribution in fish postlarvae.

Acknowledgements. We thank Captain Dowell, the officers. and the crew of RV 'Frederick Russell' for assistance at sea. P. R. G. Tranter, L. Kerslake, S. Moreau, P. C. Sroczynski, E. Bonneau, S. Blais, and M.-C. Roy assisted with sample analysis. Financial support for part of this work was received from the Ministry of Agriculture, Food and Fisheries (UK), the Department of Fisheries and Oceans Canada, and the Natural Sciences and Engineering Research Council of Canada. Three anonymous reviewers provided helpful comments.

\section{LITERATURE CITED}

Aray, M. N., Hay, D. E. (1982). Predation by medusae on Pacific herring (Clupea harengus pallasi). Can. J. Fish. Aquat. Sci. 39: 1537-1540

Bailey, K. M. (1984). Comparison of laboratory rates of predation on five species of marine fish larvae by three planktonic invertebrates: effects of larval size on vulnerability. Mar. Biol. 79: 303-309

Beyer, J. E., Laurence, G. C. (1980). A stochastic model of larval fish growth. Ecol. Modelling 8: 109-132

Brownell, C. L. (1985). Laboratory analysis of cannibalism by larvae of the Cape anchovy Engraulis capensis. Trans. Am. Fish. Soc. 114: 512-518

Chesson, J. (1978). Measuring preference in selective predation. Ecology 59: 211-215

Cushing, D. H. (1974). The possible density-dependence of larval mortality and adult mortality in fishes. In: Blaxter, J. H. S. (ed.) The early life history of fish. Springer-Verlag, New York, p. 103-112

Cushing, D. H. (1983). Are fish larvae too dilute to affect the density of their food organisms? J. Plankton Res. 5: $847-854$

Dagg, M. J., Clarke, M. E., Nishiyama, T., Smith, S. L. (1984). Production and standing stock of copepod nauplii, food items for larvae of the walleye pollock Theragra chalcogramma in the southeastern Bering Sea. Mar. Ecol. Prog. Ser. 19: $7-16$

Folkvord, A., Hunter, J. R. (1986). Size-specific vulnerability of northern anchovy, Engraulis mordax, larvae to predation by fishes. Fish. Bull. U.S. 84: 859-869

Frank, K. T (1986). Ecological significance of the ctenophore Pleurobrachia pileus off southwestern Nova Scotia. Can. J. Fish. Aquat. Sci. 43: 211-222

Frank, K. T., Leggett, W C. (1985). Reciprocal oscillations in densities of larval fish and potential predators: a reflection of present or past predation? Can. J. Fish. Aquat. Sci. 42: $1841-1849$

Fraser, J. H. (1970). The ecology of the ctenophore Pleurobrachia pileus in scottish waters. J. Cons. int. Explor. Mer 33: $149-168$

Fraser, D. F., Sise, T E. (1980). Observations on stream minnows in a patchy environment: a test of a theory of habitat distribution. Ecology 61 790-797

Fretwell, S. D., Lucas, H. L., Jr (1970). On territorial behavior and other factors influencing habitat distribution in birds. Acta biotheor. 19: 16-36

Gliwicz, M. Z. (1986). Predation and the evolution of vertical migration in zooplankton. Nature, Lond. 320: 746-748

Godin, J.-G. J., Keenleyside, M. H. A. (1984). Foraging on patchily distributed prey by a cichlid fish (Teleostei, Cichlidae): a test of the ideal free distribution theory. Anim. Behav. 32: 120-131

Govoni, J. J., Boehlert, G. W., Watanabe, Y (1986a). The physiology of digestion in fish Iarvae. Environ. Biol. Fish. 16: $59-77$

Govoni, J. J., Ortner, P. B., Al-Yamani, F., Hill, L. C. (1986b). Selective feeding of spot, Leiostomus xanthurus, and Atlantic croaker, Micropogonias undulatus, larvae in the northern Gulf of Mexico. Mar. Ecol. Prog. Ser. 28: 175-183

Grubb, T. C., Jr, Greenwald, L. (1982). Sparrows and a brushpile: foraging responses to different combinations of predation risk and energy cost. Anim. Behav. 30: 637-640

Harris, R. P., Fortier, L., Young, R. K. (1986). A large-volume pump system for studies of the vertical distribution of fish larvae under open sea conditions. J. mar. biol. Ass. U. K. 66: $845-854$

Holbrook, S. J., Schmitt, R. J. (1988). The combined effects of predation risk and food reward on patch selection. Ecology 69: $125-134$

Hughes, R. N. (1980). Optimal foraging theory in the marine context. Oceanogr. mar. Biol. A. Rev. 18: 423-481

Hunter, J. R. (1984). Inferences regarding predation on the early life stages of cod and other fishes. Flod. Rapp. 1: 533-562

Hunter, J. R., Thomas, G. L. (1974). Effect of prey distribution and density on the searching and feeding behaviour of larval anchovy Engraulis mordax Girard. In: Blaxter, J. H. S. (ed.) The early life history of fish. Springer-Verlag, New York, p. 559-574

Iwasa, Y. (1982). Vertical migration of zooplankton: a game between predator and prey. Am. Nat. 120: 171-180

Jenkins, G. P. (1987). Comparative diets, prey selection, and predatory impact of co-occurring larvae of two flounder species. J. exp. mar. Biol. Ecol. 110: 147-170

Johnsen, G. H., Jakobsen, P. J. (1987). The effect of food limitation on vertical migration in Daphnia longispina Limnol. Oceanogr. 32: 873-880

Jones, R. (1973). Density dependent regulation of the numbers of cod and haddock. Rapp. P.-v. Cons. int. Explor. Mer 164 $156-173$

Kane, J. (1984). The feeding habits of co-occurring cod and haddock larvae from Georges Bank. Mar. Ecol. Prog. Ser 16: $9-20$

Kuhlmann, D. (1977). Laboratory studies on the feeding behaviour of the chaetognaths Sagitta setosa J. Müller and $S$ elegans Verrill with special reference to fish eggs and larvae as food organisms. Kieler Meeresforsch. 25: $163-171$

Last, J. M. (1980). The food of twenty species of fish larvae in the west-central North Sea. Fish. Res. Tech. Rep. MAFF Direct. Fish. Res., Lowestoft 60: 1-44

Lebour, M. V. (1923). The food of plankton arganisms. J. mar. biol. Ass. U.K. 12: 644-677

Milinski, M. (1979). An evolutionary stable feeding strategy in sticklebacks. 2. Tierpsychol. 51-36-40

Milinski, M. (1986). Constraints placed by predators on feeding behaviour In: Pitcher, T J. (ed.) The behaviour of teleost fishes. Croom Helm, London, p. 236-252 
Milinski, M. (1987). Competition for non-depleting resources: the ideal free distribution in sticklebacks. In: Kamil, A. C., Krebs, J. R., Pulliam, H. R. (eds.) Foraging behavior Plenum Press, New York, p. 363-388

Milinski, M. Heller, R. (1978). Influence of a predator on the optimal foraging behaviour of sticklebacks (Gasterosteus aculeatus L.). Nature, Lond. 275: 642-644

Möller, H. (1984). Reduction of a larval herring population by jellyfish predator Science 224: 621-622

Monteleone, D. M., Peterson, W. T. (1986). Feeding ecology of American sand lance Ammodytes americanus larvae from Long Island Sound. Mar Ecol. Prog. Ser 30: 133-143

Munk, P., Kiørboe, T. (1985). Feeding behaviour and swimming activity of larval herring (Clupea harengus) in relation to density of copepod nauplii. Mar. Ecol. Prog. Ser. 24: 15-21

Oresland, V (1987). Feeding of the chaetognaths Sagitta elegans and $S$. setosa at different seasons in Gullmarsfjorden, Sweden. Mar Ecol. Prog. Ser. 39: 69-79

Pearre, S. (1982). Estimating prey preference by predators: uses of various indices, and proposal of another based on $\chi^{2}$ Can. J. Fish. Aquat. Sci. 39: 914-923

Pedersen, B. H. (1984). The intestinal evacuation rates of larval herring (Clupea harengus L.) predating on wild plankton. Dana 3: 21-30

Pepin, P. (1987). Influence of alternative prey abundance on pelagic fish predation of larval fish: a model. Can. J. Fish. Aquat. Sci. 44: 222-227

Peterson, W. T., Ausubel, S. T (1984). Diets and selective feeding by larvae of Atlantic mackerel Scomber scombrus on zooplankton. Mar. Ecol. Prog. Ser 17: 65-75

Power, M. E. (1984). Habitat quality and the distribution of algae-grazing catfish in a Panamanian stream. J. Anim. Ecol. 53: 357-374

Purcell, J. E. (1985). Predation on fish eggs and larvae by pelagic cnidarians and ctenophores. Bull. mar Sci. 37 : $739-755$

Purcell, J. E., Siferd, T. D., Marliave, J. B. (1987). Vulnerability of larval herring (Clupea harengus pallasi) to capture by the jellyfish Aequorea victoria. Mar Biol. 94: 157-162
Rothschild, B. J. (1986). Dynamics of marine fish populations. Harvard University Press, Cambridge, Mass.

Russell, F. S. (1976). The eggs and planktonic stages of British marine fishes. Academic Press, London

Schmitt, P. D. (1986). Feeding by larvae of Hypoatherina tropicalis (Pisces: Atherinidae) and its relation to prey availability in One Tree Lagoon, Great Barrier Reef. Australia. Environ. Biol. Fish. 16: 79-94

Shepherd, J. G., Cushing, D. H. (1980). A mechanism for density-dependent survival of larval fish as the basis of a stock-recruitment relationship. J. Cons. int. Explor Mer 39: $160-167$

Sissenwine, M. P. (1984). Why do fish populations vary? In: May, R. M. (ed.) Exploitation of marine communities. Dahlem Konferenzen, Berlin. Springer-Verlag, Berlin, p. 59-94

Southward, A. J., Barrett, R. L. (1983). Observations on the vertical distribution of zooplankton, including postlarval teleosts, off Plymouth in the presence of a thermocline and a chlorophyll-dense layer J. Plankton Res. 5: $599-618$

Taggart, C. T., Leggett, W C. (1987). Short-term mortality in post-emergent larval capelin Mallotus villosus. II. Importance of food and predator density, and density-dependence. Mar. Ecol. Prog. Ser. 41: 219-229

Theilacker, G., Dorsey, K. (1980). Larval fish diversity, a summary of laboratory and field research. Intergovernmental Oceanographic Commission. Workshop Rep. No. 28: $105-142$

Venrick, E. L. (1986). The Smirnov statistic: an incorrect test for vertical distribution patterns. Deep Sea Res. 33: $1275-1277$

Ware, D. M. (1975). Relation between egg size, growth, and natural mortality of larval fish. J. Fish. Res. Bd Can. 32: $2503-2512$

Williams, R., Collins, N. R. (1985). Chaetognaths and ctenophores in the holoplankton of the Bristol Channel. Mar Biol. 85: 97-107

Wyatt, $T$ (1972). Some effects of food density on the growth and behaviour of plaice larvae. Mar. Biol. 14: 210-216

This article was presented by Dr K. Sherman; it was accepted for printing on November 1, 1988 